\title{
Erratum to: 'Effect of a high-dose target- controlled naloxone infusion on pain and hyperalgesia in patients following groin hernia repair: study protocol for a randomized controlled trial'
}

Manuel Pedro Pereira ${ }^{1,2^{*}}$, Mads Utke Werner ${ }^{2}$ and Joergen Berg Dahl ${ }^{1}$

Unfortunately, the original version of this article [1] contained an error. The author names were displayed incorrectly, Pereira MP, Utke Werner M, Berg Dahl J. The should have been written as follows: Pereira MP, Werner MU and Dahl JB.

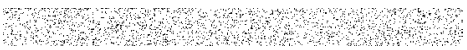

\section{Reference}

1. Pereira MP, Werner MU, Dahl JB. Effect of a high-dose target-controlled naloxone infusion on pain and hyperalgesia in patients following groin hernia repair: study protocol for a randomized controlled trial. Trials. 2015;16:511.

* Correspondence: mpereira@anit.uni-muenster.de

${ }^{1}$ Department of Anaesthesiology, Centre of Head and Orthopaedics, Rigshospitalet, Copenhagen University Hospitals, Copenhagen, Denmark ${ }^{2}$ Multidisciplinary Pain Center, Neuroscience Center, Rigshospitalet, Copenhagen University Hospitals, Copenhagen, Denmark
Submit your next manuscript to BioMed Central and we will help you at every step:

- We accept pre-submission inquiries

- Our selector tool helps you to find the most relevant journal

- We provide round the clock customer support

- Convenient online submission

- Thorough peer review

- Inclusion in PubMed and all major indexing services

- Maximum visibility for your research

Submit your manuscript at www.biomedcentral.com/submit 